\title{
Continuity and change in Italian discourse on migration: A focus on mainstream television documentaries
}

Paolo Orrù, University of Debrecen

\begin{abstract}
The goal of this article is to employ the means of critical discourse analysis to verify the contribution made by news documentaries to the discussion on the topic of migration in Italian journalism. My case studies include three documentaries screened on the national broadcaster (RAI): La neve la prima volta (Snow for the First Time) (Cataldi, 2014), Quando Youssef si mise in cammino (When Youssef Started His Walk) (Cataldi, 2015) and La lunga Marcia (The Long Route) (Ricucci, 2015). The documentaries deal with a range of issues regarding migration in the European Union, such as the construction of European external borders; policies of migrant management; human rights; prejudice towards foreigners. The article will take a closer look at lexical terms, metaphors and other rhetorical forms. Linguistic evidence has been jointly analysed with the visual construction on-screen since they both participate in the meaning-making process of the documentary as a whole.
\end{abstract}

\section{Keywords}

discourse analysis; migration; racist discourse; documentary; Italy; European Union; Italian television; RAI

\section{Introduction}

Italy has undergone major changes in its demographic structure over the last twenty years: in the first decade of the twenty-first century, the foreign population rose from 1.3 million in 2001 to almost five million in 2014. Italian society has had to face an ever-changing and growing 
number of changes and all the implications of a late approach to globalization. Every day, migrants, refugees and asylum seekers receive harsh treatment or are victims of downright hostility, which are mostly based on economic and cultural factors (Balibar 1991), as contemporary racism in the second half of the twentieth century moved away from its biological basis and realized new forms of exploitation (Van Dijk 2000).

A number of previous studies have highlighted the central role played by mainstream journalism in the reproduction of stereotypes and inaccurate representations of migration. For instance, even though only a small share of migrants actually arrive by sea each year, ${ }^{1}$ most of the representations of the migratory process have concentrated on depicting migrants arriving by boat, either from Albania in the early and mid-1990s (Montali et al. 2013) or from Africa and the Middle East throughout the following decade (Orrù 2015). Images of battered ships overcrowded with African people soon became an extremely common sight for the Italian audience. Indeed, it became a sort of paradigm of the entire phenomenon. At the same time, the press (Maneri 1995; Binotto and Martino 2004; Taylor 2009) and news reports (Bruno 2012), portrayed foreigners as being increasingly associated with crime and violent acts, fostering a sense of alarm and danger in the population (Dal Lago 1998, 2009; Ter Wal 2001).

Notably, from the early 1990s onwards, mass migration started to be addressed by Italian artists and filmmakers in an ever increasing number of productions and documentaries. ${ }^{2}$ Documentary films emerged as one of the most active and innovative genres in Italian production (Angelone and Clò 2011) with a renewed interest for social and political issues and marginalized subjects such as migrants or the LGBT population. As a matter of fact, documentaries have proven to be a fertile ground for filmmakers to express their point of view on the migratory process, allowing it to be portrayed from different angles and, at the same time, challenging its mainstream representation, as underlined by Michela Ardizzoni: 
In the new millennium, the Italian documentary scene demonstrates that the production of images of social change can effectively contribute to broaden an often-stifling public sphere and include in the debate groups that have notoriously been marginalized by mainstream media. As such, contemporary documentaries represent a successful form of counterdiscourse in Italian media and society that targets trite notions of political engagement (understood as impegno) by centring on disenfranchised subjects in participatory and productive ways. (2013: 312)

However, documentaries are also a well-established genre with a long tradition in public service broadcasting (Aufderheide 2007). They could even be considered as a genre of 'factual television', ${ }^{3}$ that is, a kind of production that represents selected aspects of reality and from which the public expects a certain degree of trustworthiness. The journalist is regarded as an expert or a source of mostly factual and objective information, and his or her presence onscreen (or as a voice-over) confers credibility to the programme and bolsters its claims about what is being displayed.

As a lengthy investigation on a single and salient issue, while still incorporated within the overall news discourse, television news documentaries contrast with the on-going flux of information provided by all-news channels or real time updates from news websites. Above all, however, they differentiate themselves from traditional television news reports because, while the latter offers little room for alternative and unconventional interpretations of an issue, television documentaries 'permit investigations into the causes and effects of an issue and provide space for the expression of positions critical of prevailing political and social conditions' (Beattie 2004: 162). 
Just like any other filmic product, documentaries are based on the complex interplay between images, sounds and words. The audience experiences both the visual, audio, and narrative aspects of the film simultaneously, hence the interaction between the mise-en-scène and the linguistic description of places, characters, and events is a crucial part in the meaningmaking process of the film. Seen through the lenses of Norman Fairclough's definition of language as 'social practice determined by social structures' (1989: 17), language and discourse play a major role in the process of forming identities, knowledge and relationships. Thus, texts (oral, written or multimodal) have a dialogic relationship with social matters, constantly shaping the reality in which we live (Fairclough 1995a: 55). Language expresses power relations within a society and, thus, the ways in which the elite describe social actors can potentially marginalize subjects. This interconnection, however, should not be taken in a straightforward way: even though mainstream and institutional discourse tend to reflect existing relations of power and hegemony, at the same time, discourse permits the very same possibility of a counter hegemonic response and change.

Furthermore, from a linguistic point of view, public service and news broadcasting ${ }^{4}$ actually contributed to the process of social and linguistic unification in Italy, by actively shaping and spreading a common Italian spoken language throughout the population in the period after the Second World War (Mengaldo 1994; De Mauro 1963).

The main goal of this contribution is to employ the means of critical discourse analysis (Fairclough 1989, 1995a) to verify the contribution made by news documentaries to the broad discussion on the topic of migration in Italian journalism.

The term critical discourse analysis is used nowadays to refer more specifically to the critical linguistic approach of scholars who find the larger discursive unit of text to be the basic unit of communication. This research 
specifically considers institutional, political, gender and media discourses (in the broadest sense) which testify to more or less overt relations of struggle and conflict. (Wodak 2001: 2)

In this view, the lexical, syntactic or textual linguistic choices included in a text should be considered as a meaningful part in the social construction of reality and in the development of specific forms of knowledge (i.e. discourses) (Fairclough 1995b: 18). The study will therefore take a closer look at referential strategies (i.e. the ways in which social actors are described via lexical terms, deixis and adjectives), metaphors, and other rhetorical forms (such as synecdoche or hyperboles). Linguistic evidence has been jointly analysed with the visual construction onscreen since they both participate in the meaning-making process of the documentary as a whole.

The study of television news or programmes is not a novelty in the field of critical discourse studies, nevertheless, previous studies on the issue of migration in the Italian context mainly focused on a quantitative analysis of traditional news broadcasts (Binotto and Martino 2004; Vaccari 2010; Bruno 2012). Therefore, a discourse analysis of news documentaries grounded in the linguistic field could prove useful in the analysis of this peculiar aspect of news discourse.

Finally, in order to explore the possibility of a new emerging discourse in mainstream Italian media, this study focuses on three news documentaries screened by the Italian national public broadcasting company (Rai), and thus considered as part of everyday news discourse.

\section{Corpus}

The corpus is composed of three documentaries: two by Valerio Cataldi and one by Amedeo Ricucci. Cataldi's films were produced and aired by $\operatorname{Tg} 2$ under the patronage of United Nations 
High Commissioner for Refugees (UNHCR). They depict two different facets of the migrants' experience. In La neve la prima volta (Snow for the First Time) ${ }^{5}$ (Cataldi, 2014), the director focuses on the stories of four survivors from the shipwreck that happened off Lampedusa on 3 October 2013, resulting in 366 deaths. The aim of the documentary is to use these narratives to highlight the limits and failures of Italian refugee and migrant management policies.

Quando Youssef si mise in cammino (When Youssef Started His Walk) (Cataldi, 2015) is the second part of Cataldi's endeavour to recount migration. The documentary tells the story of Youssef and his three friends as they travelled from Afghanistan to Austria in search of asylum. In both of Cataldi's films, the voice-over is done by famous Italian actors (such as Francesco Pannofino and Nicolas Vaporidis) in order to give visibility to the story of people who otherwise would have remained invisible to the general public.

Similarly, La lunga marcia (The Long Route) (2015) by Amedeo Ricucci follows the journey of Syrian refugees in their attempt to reach Europe during the summer of 2015. Although their route does not take them across the Italian border, the documentary represents an interesting gaze on a very salient topic in the contemporary Italian public debate, and therefore provides the audience with a new perspective on migration.

The three documentaries deal with a wide set of issues regarding migration in Italy and the European Union, such as the construction of European external and internal borders; policies and practices of migrant management; human rights, and racism and prejudice towards foreigners.

\section{La neve, la prima volta (Snow for the First Time)}

The documentary opens with the sound of footsteps off-screen followed by a series of images of snowy landscapes. Cataldi and the first character, Adal, walk across a snow-covered field and talk about life in Sweden. The snow not only represents Northern Europe and those 
countries where refugees seek asylum, but also stands for the possibility that Eritreans, and migrants in general, can travel freely across the world. This interpretation is strongly conveyed by the first words spoken by the narrator via the rhetorical parallelism between the snow ('neve') and the sun ('sole'). In this case, these two elements stand for much more than the opposition between North and South, since they also represent the contrast between freedom sought in Europe and the suffering experienced in Eritrea: 'This is the story of Adal, who saw snow (emphasis mine) for the first time at 27 and who hasn't seen the Eritrean sun (emphasis mine) for twelve years, since when he was forced to flee'.

Sweden, as well as The Netherlands and Norway, is also openly compared to Italy, from which asylum seekers try to escape in their quest to reach Northern Europe, where they 'know that greater opportunity lies beyond the snow'. The images shot inside the Lampedusa reception centre, with its squalid conditions, wrecked toilets, people sleeping outside or on the floor are juxtaposed with those of a corresponding structure in the Netherlands, where asylum seekers get proper bedrooms, food and legal assistance.

From the beginning, Cataldi adopts a critical stance towards Italian policies of migration management: 'This is the story of a country, our country, with its abstract concept of hospitality'. These words are uttered over the images of the 'anti-scabies showers' (docce antiscabbia) in Lampedusa, a controversial measure to which each and every migrant was subjected. The camera progressively moves towards the censored naked body of a migrant, who is being washed with disinfectant out in the open by one of the volunteers, an emblematic episode of 'the management and the objectification of the migrants' bodies' which also represents the repressive nature of the Bossi-Fini law (Benelli 2010: 219).

Cataldi moves from this critical perspective to narrate the complex situation of Mediterranean migration through a series of interviews with the protagonists of the documentary. They are the survivors of the disastrous sinking of their boat on 3 October 2013. 
This specific event caused 366 deaths and sparked a major public outcry. Former Italian Prime Minister Enrico Letta and the former President of the European Union commission José Manuel Barroso visited the island of Lampedusa where they were met with a strong protest from the population. In the following days, a state funeral was held for the victims. Such an honour had never been previously granted to migrants, and as one of the Nation's symbolic rituals, normally reserved for Italian citizens alone, it represented an attempt by the government to try and convey a message of inclusion.

The opposition between the members of a community, the nation, and what is perceived as the other, namely, the foreigner, is typically rendered in racist discourse by the opposition between 'us' and 'them'. Instead, Cataldi refuses this opposition: migrants are always called by their name and possess a clear individuality and personality, while, by using the first person plural, in phrases like 'force us to' or 'our country', he is also able to convey an assumption of responsibility on the part of his national community.

The documentary also contains other kinds of yideo and audio material, such as the audio recording of the conversation between the Coast Guard and the fishermen who spotted and rescued the sinking ship. From a linguistic point of view, it is also worth mentioning the immediate and uncontrolled use of the word 'clandestini' by the fishermen, since it is one of the most used - and abused - by mainstream Italian journalists, and one of the most problematic (Orrù 2015). The use of this word, or similar bureaucratic definitions such as illegal immigrant, has the effect of turning a temporary condition (crossing the border) into a permanent one, triggering and reinforcing the automatic association between foreigner and criminal. In open contrast to this practice, Cataldi tends to employ more neutral terms like profughi, migranti, richiedenti asilo (refugees, migrants, asylum seekers).

The documentary features a continuous switch of perspectives: the montage alternates the interviews with the protagonists experiencing their new life in Northern Europe with the 
retelling and memories of what happened during their voyage and their time in Lampedusa. In order to do this, Cataldi inserts video footage shot by the migrants themselves, which includes incredibly striking images of the afore-mentioned anti-scabies showers filmed inside the Lampedusa camp. But the audience is also able to see first-hand the extensive preparations made before they set out from Libya and their boat journey, or again the scene of a family having fun at the seaside the day before their departure. This raw footage not only allows the migrants to take an active part in the meaning-making process, but also has the power to humanize the characters by showing and verbalizing their hopes, anxieties, and fears, and making the emotional side of the migratory experience visible to the audience with real and concrete cases that are seldom explored in mainstream journalism.

The choice to employ several famous actors to dub the migrants is undoubtedly one of the most prevalent stylistic aspects of the film. The aim, as stated by the director, is to amplify the migrants' voices through the engagement of characters known to the wide audience of news broadcasting and television. As Cataldi himself clearly stated in the press report that accompanies the documentary:

They are invisible persons who are normally voiceless and faceless. Since they are refugees they have the right to remain anonymous in order to avoid persecution against their families in their home country. They are people who speak poor English and, in some cases, only Tigrinya, their Eritrean native language. This was what prompted us to give them visibility by using wellknown voices, famous voices, capable of interpreting the need for their stories to be revealed. Stories that are also those of others who survive war, dictatorship, desert raiders and shipwrecks like the one that happened on 3 October, only to find an abstract concept of hospitality, which can take the 
form of a hose-pipe used to administer a precautionary measure that is a cruel act at the same time. ${ }^{6}$

The importance attributed to this aspect is evident from the very beginning of the film. In fact, the names of the cast are the first to be displayed in the opening titles, following the UNHCR logo, and before any other image. This choice, however, bears a critical downside: dubbing the migrants could also cause their individuality to be anonymized, in some way diminishing or marginalizing their experience. The voices of the actors who interpret their words and their emotions have the effect of modifying and polishing the true expression of their feelings and experiences. ${ }^{7}$

Nevertheless, the four migrants are the core of the documentary and their stories and the interviews allow the audience to observe some of the less represented aspects of the migratory process from Africa. This holds particularly true for the story of Adal, who describes the torture he suffered in Eritrea where he was deported after being arrested for illegal immigration in Malta. The journalist steps back and leaves space for Adal to tell his story and, as the music moves from dramatic to more obscure tones, the camera focuses alternatively on his hands and on the shocking drawings of the acts of torture inflicted by the Eritrean police. This section constitutes a strong visual representation of what occurs in everyday discourse where migrants are generally described, often with a superficial and pietistic attitude, as desperate people fleeing war, oppression and poverty (Orrù 2015), while Italy's colonial past and its consequences are totally discarded and barely mentioned.

On the whole, migrants are represented as positive characters: they work and pay taxes, and report smugglers to the authorities, a decision that costs them months of detention in Lampedusa as they wait to testify in the trial against their persecutors, thus characterizing them as honest persons willing to cooperate with the Italian authorities. 
The filmmaker puts much emphasis on the attempt to humanize asylum seekers, by telling their life story in great detail, describing their aims, their migratory project and their suffering. As an exemplum, the story of these four persons could by analogy represent the stories of thousands of other migrants. The exemplum is one of the most powerful rhetorical strategies employed in both racist and anti-racist discourse: 'it often also implies that the case being told about is typical, and hence may be generalized' (Van Dijk 2000: 70). Those cases that can be interpreted as the most extreme ones selected by the journalist are in fact representative of the common experience of thousands of people who leave their countries each year to come to Europe.

\section{Quando Youssef si mise in cammino (When Youssef Started His Walk)}

The second chapter of Cataldi's work on migration, Quando Youssef si mise in cammino, starts with almost the same configuration as the previous one: the opening titles show the names of the cast of Italian actors and the sound of footsteps off-screen introduces the viewer to the main theme of the documentary - the migrants' journey along terrestrial routes. After having shown the much more familiar side of migration, that is to say by sea, the director focuses his lens on the most common method for entering Europe, namely, on foot. Hence, Cataldi highlights a fact that is often omitted in everyday reports on the issue, but clearly stated in one of the first scene of the film: 'figures say that the number of people who walk this route are three times as many as those who choose to set off by boat [from Libya] to reach Europe'.

The documentary is divided into various sections, each representing a different leg of the journey from Syria or Afghanistan to Europe. Every section is introduced by a map showing the route and the distance travelled by the migrants, corresponding to a new border to trespass.

The theme of the march is embedded in the very core of the documentary, which is in fact stylistically characterized by an enormous number of close-ups of the migrants' feet. As the 
journey is entirely completed on foot, feet function as a visual type of a pars pro toto synecdoche; they stand for the migrants themselves and their experience. The camera also repeatedly moves from mid- to long-range shots of migrants marching through fields, which makes the distance they progressively cover in both space and time more visible to the audience. These combined aspects clarify the main point of the documentary: the incoherence of European policies on the issue and the rigid rules governing admission of refugees to the Union force asylum seekers to undertake painful and excessively long journeys to escape war and oppression in their native country.

The documentary constantly confronts the audience with the physicality of the border. Whereas in La neve la prima volta migrants experienced the trespassing of a territorial sea and the border was mainly represented by the invisible bureaucratic apparatus of norms and policies regulating conditions for entry to Europe, in this second chapter, the director captures the frontiers in their more visible and tangible manifestation. The militarization of migratory policies, summarized in the metaphor of 'fortress Europe', is a well-known aspect of the material construction of (trans)national identity. The images of numerous checkpoints, barbed wire barriers and the constant presence of police and military forces to push back or imprison migrants in various countries (Greece, Spain, Macedonia and Serbia) have the effect of revealing an entire set of linguistic tools typical of political and news discourse. The visual representation of immigration in Italy, as previously mentioned, has been limited throughout the years to the depiction of arrivals by sea, in the form of people being rescued from battered ships and boats or overcrowded Centri di prima accoglienza (Initial reception centres) in Lampedusa. While right-wing parties and newspapers employ a military lexicon to describe the migratory process, using words like 'invasion' or 'army of immigrants' (Orrù 2015), the documentary clearly shows the reality behind all these terms. The army of immigrants ready to raid Italy is embodied by families, old people and children, who have undergone great suffering 
and are fleeing from military or religious oppression in their country. This also has the effect of reversing the racist discourse rhetoric by showing the audience what this so-called 'army' really looks like.

Refugees also have to face natural borders such as rivers, swamps and woods, which represent a frontier zone where they have to hide while waiting for their chance to cross the border. In the second section, Cataldi visits Orestiada and the river Evros, where he collected the stories of entire families and parents who faced death or saw their children die on the journey. A typical strategy used by news discourse is to rely on 'sentimentality' (Richardson 2007: 124-15), that is the use of women and children, portrayed as weak and sensitive figures, which has a strong emotional appeal for the audience. Sentimentality is often deployed in the discourse about migration, and most of the time serves to boost a positive self-presentation (Van Dijk 2000) of Italy in the shape of Italian volunteers and military forces rescuing and looking after boat people (Bruno 2012). However, in this case the strategy is utilized to amplify the criticism of Europe and its immigration policies.

In everyday news discourse, migrants often tend to appear in long shots, in which they are an indistinct conglomerate, barely recognizable as human beings (Richardson and Colombo 2013); the same effect is obtained in newspapers by an extensive use of figures (Van Dijk 1988: 87-88) and strategies of linguistic aggregation. ${ }^{8}$ Both these strategies result in a dehumanization of migrants, since their individuality is totally deleted from the scene, hence making it difficult for the audience to empathize with them and even to recognize them as human beings. By contrast, Cataldi tells the audience real stories: asylum seekers have names, faces and, above all, a story to tell. The extreme close-ups of their faces, their hands, their feet, but also of their few belongings and baggage show the audience the conditions in which they live and make every detail real and vivid. 
Quando Youssef si mise in cammino goes a step further than the previous chapter towards direct participation in the subject of the film. Cataldi does not tell the stories after they occurred, but partly lives the experience of the journey, following various groups of migrants across the most salient borders and looking for those places where he was more likely to meet them and hear their stories. But this is always done from the journalist's viewpoint: he decides which route the viewer has to follow. Sometimes he walks with and accompanies migrants. At other times, he moves alone with his crew from point to point. The camera alternates close shots and hand-held camera with long shots of people marching, so that the authorial hand is always visible to the audience.

More than Italy itself, Cataldi is criticizing Europe, the EU and its policies. The refugees do not cross the Italian border and Italian policies are not directly addressed, the documentary could therefore be considered as part of the contemporary discourse on the state of the European Union, its political limitations and divisions. Hence, Quando Youssef si mise in cammino partly overlaps the recurrent topic in the Italian public debate on the anti-EU discourse regarding migratory issues and the cost of their management.

\section{La lunga marcia/The Long Route}

In La lunga marcia, screened by RAI Uno, the main channel of the Italian public service broadcasting company, the journalist follows the journey of a group of Syrian asylum seekers from the Greek shores of Lesbos to Vienna during the summer of 2015. This was when the refugee crisis had reached its peak and when Germany and Austria offered to give hospitality to thousands of people against the blockade and decision of the Hungarian government to seal its borders and push back migrants.

The documentary opens with the head titles giving a brief summary of the context. The last paragraph of the headlines also introduces us to the specific kind of approach that has been 
used to tell the migrants' story: the journalist, the main protagonist of the documentary, travelled alongside various groups of Syrians as they crossed the borders. From a linguistic point of view, the use of the inclusive 'we' ('we have travelled') and the adverbial ('together') signals the participatory attitude of the journalist towards the migrants: "what follows is the story of the long journey we undertook together with them: from the Greek islands to Vienna, passing through Macedonia, Serbia, Croatia and Hungary'.

The documentary has a similar structure to that of Quand Youssef si mise in cammino, but La lunga marcia has a more fluid narrative and relies less on alternate montage techniques. The story is unveiled in chronological order that mirrors the different stages of the journey.

The first scene opens with the voice-over of a migrant, dubbed in Italian, asking for help; the frame is divided with a split screen showing a map, indicating the different stages of the route through Greece, Macedonia, Serbia, Turkey Hungary and Austria, and a group of migrants on a boat, one of the famous barconi, which is clearly a familiar sight for the Italian audience. The journalist and the cameraman are caught up in the midst of the arrival of three boats rescued by the coastguard. The sequence - as well as the whole film - is shot with a hand-held camera that gives an immediate sense of reality and immersion.

Then, Amedeo Ricucci, the journalist, interviews some of the refugees in order to immediately contextualize their experience; nevertheless, the linguistic tone of the journalist is actually the most critical aspect of the whole documentary. Even though some of the interviewees were able to speak a little English, the linguistic choices made by the interviewer are affected by stereotypes. Therefore, the overall didactic tone of the questions in this first scene has the effect of infantilizing the interlocutors, not only by the oversimplification of the language, which could be functional to mutual comprehension, but also by the oversimplification of the content. For instance, Ricucci asks the group of refugees who have just disembarked from the boats whether they had known that the journey to Europe would 
have been such a 'long and hard' one ('Did you know that the journey to Europe was so long and hard?'). Women are then identified as the weak element in the group, ('Are the women scared?'): this kind of phrasing is driven by the assumption that men are not normally afraid of the hardships encountered on the journey, whilst women are. Finally, the journalist asks them which side (Assad or Daesh) was the most 'cattivo' (evil) in the Syrian war. Even though these fragments give the migrants the opportunity to introduce their point of view, their fears and their reason for fleeing their country, the didactic tone is rather reminiscent of a sense of superiority towards black people, and foreigners in general, common to Italian media discourse.

As in the previous cases, La lunga marcia sees the filmmaker include materials from other media, such as the story of Ahmad, the pianist from Yarmuk. Ahmad became famous because of the videos that showed him playing the piano amidst the ruins of Ismir, his native city in Syria, during a Daesh military advance. Ahmad's videos quickly went viral and circulated on the Internet reaching other traditional national broadcasters, such as the BBC and the Rai. The lengthy interview with Ahmad is also the chance for migrants to talk back and criticize Europe's failure to react to the Syrian civil war.

During the journey, the involvement expressed by the constant use of inclusive forms, 'there are around 2000 of us, maybe more, we've been waiting for two hours', 'they forced us to stand in a line' or 'our group', is simultaneously in sharp contrast with the factual otherness of the journalist, who can travel around freely by car, be the first to board a ferry or even afford a taxi to get to the train station.

As in the other documentaries, several close-ups of the migrants' faces, feet or their belongings are employed to emphasize their state of mind and feelings, in order to generate empathy and an emotional response from the audience.

The role of metaphor in everyday discourse and communication has been a constant object of enquiry since the ground-breaking theories on the conceptual metaphor and its cognitive 
function in structuring thoughts, developed by Lakoff and Johnson (1980). In racist discourse the metaphor of 'immigration as a river or flood' is well known on a transnational level (Reisigl and Wodak 2001; Gabrielatos and Baker 2008; Orrù 2015). The images of an unstoppable flow of water running against the banks of a river or breaking a dam are frequently associated with numbers of immigrants ready to cross the European borders and invade countries, evoking the feeling of something dangerous and threatening for the nation. Another recurrent metaphor, found within the wider conceptual metaphor of the nations as a body, ${ }^{9}$ is that of migration as an epidemic or an infection and hence, intergroup relations are regarded as being dangerous for the population.

Ricucci uses both these metaphors in his description of a late-night walk across the Macedonian borders to get to Serbia:

It is as if Europe wanted to hide this river of refugees that flows within her, in fact she tries to embank it and divert it onto secondary roads, so that nobody could be infected by its waters that are considered impure.

In this case, the journalist's intent is to lay the blame on European politics for its hypocrisy and poor handling of the situation: in so doing, he relies on a set of metaphors and linguistic tools employed in the canonical representation of migration in news discourse. In a way, this particular aspect reflects the potential ambivalence of discourse: the first part of the period employs the common metaphor of migration as an uncontainable phenomenon ${ }^{10}$ ('migration as a flow'), while the second part includes a critique of European institutions: the verb 'considered' (considerate) indicates that the use of the 'disease metaphor' has to be attributed to another subject, in this case the European Union. The fact that the same types of linguistic expressions could serve opposite functions (as a means of prejudice discourse and as a way to 
reverse it) somehow demonstrates the prevalence of a stereotypical racialized discourse. Ambivalence, according to Homi Bhabha (1994), is one of the predominant strategies of discursive discrimination: the constant tension between the knowledge of difference and its disavowal, between fear and desire, finds its way in discourse through a vast catalogue of stereotypes which, though contradictory at times, finally enable the construction of the racialized subject. ${ }^{11}$ It is precisely through the recognition of the other that the colonial subject, in Bhabha's theory, is able to acknowledge his own identity. From another point of view, stereotypes, in fact, fulfil two social functions: in the first place, they reinforce solidarity between members of a group by assigning them a set of specific traits; in the second place, they ascribe traits to other groups that signal the difference between 'us' and 'them' (Quasthoff 1989). This twofold mechanism is constantly employed in discourse and is «not only a very general characteristic of group conflict and the ways we interact with opposed groups, but also characterizes the way we talk about ourselves and others»(Van Dijk 2000: 44). This functional duality between self and other-identification - 'narcissism' and 'aggression' in Bhabha's terms - is what ensures the repeatability and persistence of stereotypes in discourse.

\section{Conclusions}

Adopting Nichols' terminology, we may consider the three documentaries as instances of participatory documentaries: the journalist who is the main protagonist (Cataldi on the one hand and Ricucci on the other) follows the paths of the migrants on their journey to Europe:

When we see participatory documentaries we expect to witness the historical world as represented by someone who actively engages with, rather than unobtrusively observes, poetically reconfigures, or argumentatively assembles that world. The filmmaker steps out from behind the cloak of 
voice-over commentary, steps away from poetic meditation, steps down from

a fly-on-the-wall perch, and becomes a social actor (almost) like any other. (Almost like any other because the filmmaker retains the camera, and with it, a certain degree of potential power and control over events). (Nichols 2001: 116)

This is particularly true for La lunga marcia, where the journalist takes an active part in the journey: he contributes by paying for taxis or tickets for the refugees, he travels with them on the same bus or ferry or walks with them across the borders at night.

Nonetheless, the actual point of view is always that of the director, since we are constantly reminded of the authorial choices made in order to narrate the stories in a compelling and emotional way. The soundtracks, for instance, almost always adopt a dark and sad tone to express empathy with the protagonists' feelings. Both filmmakers employ close-ups and extreme close-ups of migrants' body parts, hands, feet and faces which serve the same purpose and could be considered as a kind of visual hyperbole.

Cataldi's documentaries not only try to offer the representation of important social facts for Italy and Europe as a whole, but they also clearly speak up in favour of migrants and their right to mobility as human beings, while decrying policies that objectify and dehumanize them, as stated by Nichols:

documentaries may represent the world in the same way a lawyer may represent a client's interests: they put the case for a particular view or interpretation of evidence before us. In this sense documentaries do not simply stand for others, representing them in ways they could not do themselves, but rather they more actively make a case or argument; they 
assert what the nature of a matter is to win consent or influence opinion.

(2001: 4)

Both Quando Youssef si mise in cammino and La lunga marcia allow the audience to visualize those migratory routes that have received less attention in the mainstream media throughout the years. To a certain extent, they have provided Italian viewers with an unedited perspective. The border and the overall military apparatus that make 'fortress Europe' more than a mere metaphor appear on the screen in all their harshness. Entire families, the young and the old are pushed back, confined in detention camps or arrested and deported to their countries of origin. Both documentaries assume a critical standpoint on the matter, pointing out the inhumane treatment reserved for asylum seekers.

La lunga marcia displays the closest connection to the typical ways of depicting migration in Italian media. The journalist continuously adopts an emotional and empathic attitude towards the refugees, even though some of the linguistic strategies employed actually resemble the typical tools of prejudice discourse. As noted by O'Healy, 'mechanisms of racial differentiation do not always impose themselves in stark polarities of negativity and positivity, superiority and inferiority, inclusion and exclusion' (2009: 195). In fact, the construction of the other and his or her constitutive differences not only functions as a way to legitimate discriminatory practices, but is also a more subtle mechanism of positive self-presentation of one's own group. In Italian journalism this attitude is often well represented by the depiction of migrants as desperate, poor people in need of help who are courageously rescued by Italian people (Bruno 2012; Orrù 2015).

Overall, this study has tried to examine some of the most recent representations of migration by Italian mainstream media. Over two decades, from the early 1990s to the first decade of the twenty-first century, Italian journalism struggled in its representation of 
migration, caught between openly racist claims (found in the most aggressive right-wing newspapers such as Libero or Il Giornale) and more open but still problematic views, which tended to emphasize the positive role of the Italian institution.

The Syrian refugee crisis in 2015 saw a possible turning point. Germany's and Austria's decision to open their borders and let thousands of refugees into their countries, together with the image of Alan Kurdi's body on a Turkish beach had a global impact on public opinion. Faced with the Syrian refugee crisis, Italian documentaries definitely took a stance towards accoglienza, openly criticizing Italian and European migratory policies.

The stories told in the documentaries become paradigmatic of the complex aspects of Mediterranean migration: the critical conditions of the reception centres caused by a constant state of emergency; the bureaucratic apparatus behind the requests for asylum and the procedures that limit people's rights to move freely across borders, and the violence and oppression suffered during the long journey to Italy.

Finally, a varied set of tools typical of news discourse about migration is deployed. On the one hand, these serve to make a critical reflection on the situation and to empathize with migrants. This happens particularly in Cataldi's work, which offers a more human and positive picture of the migrants, who are described as determined, proactive, and resourceful characters, as opposed to the usual characterization found in the daily newspapers of desperate, hopeless people (Orrù 2015). On the other hand, some other more common discursive elements occasionally find their way into the narrative, such as an excessive pietism in the approach towards migrants or the use of some typical metaphors and lexical elements employed in news discourse. Globally, a concrete attempt to take a critical stance on Italian and European migratory policies and on migrant management emerges from the three documentaries, giving the general audience an inside view of the sufferance of the long and difficult journeys undertaken by asylum seekers. 


\section{References}

Angelone, A. and Clò, C. (2011), 'Other visions: Contemporary Italian documentary cinema as counter-discourse', Studies in Documentary Film, 5:2\&3, pp. 83-89.

Ardizzoni, M. (2013), 'Narratives of change, images for change: Contemporary social documentaries in Italy', Journal of Italian Cinema \& Media Studies, 1:3, pp. 311-26.

Aufderheide, P. (2007), Documentary Film: A Very Short Introduction, Oxford: Oxford University Press.

Balibar, E. (1991), 'Is there a "Neo-Racism”?', in E. Balibar and I. Wallerstein (eds), Race, Nation, Class: Ambiguous Identities, London and New York: Verso, pp. 17-28.

Beattie, K. (2004), Documentary Screens: Non-fiction Film and Television, New York: Palgrave.

Benelli, E. (2010), 'The "Other" from Another Shore: Identity at Sea in Quando sei nato non puoi più nasconderti', in G. Russo Bullaro (ed.), From Terrone to Extracomunitario: New Manifestations of Racism in Contemporary Italian Cinema, London: Troubador Publishing, pp. 219-39.

Bhabha, H. (ed.) (1994), 'The other question. Stereotype, discrimination and the discourse of colonialism', in The Location of Culture, London and New York: Routledge, pp. 66-84. 
Binotto, M. and Martino, V. (eds) (2004), FuoriLuogo: l'immigrazione e i media italiani ('Outofplace: Immigration and Italian media'), Cosenza and Roma: Pellegrini and RAI.

Bruno, M. (2012), 'Andare oltre gli stereotipi. La figura del migrante nell’informazione italiana e le ricerche per la Carta di Roma' ('Going beyond stereotypes. The image of the migrant in Italian journalism and research for the Carta di Roma'), in F. Cristaldi and D. Castagnoli (eds), Le parole per dirlo: Migrazioni, comunicazione e territorio ('The Words to Say it: Migration, Communication and Place'), Perugia: Morlacchi, pp. 49-79.

Cataldi, Vittorio (2014), La neve la prima volta (Snow for the First Time), Italy: RAI Radiotelevisione Italiana and UNHCR.

(2015), Quando Youssef si mise in cammino (When Youssef Started his Walk), Italy: RAI Radiotelevisione Italiana and UNHCR.

Dal Lago, A. (ed.) (1998), Il nemico e lo straniero: materiali per l'etnografia contemporanea ('The enemy and the stranger: Materials for contemporary ethnography'), Genova: Costa \& Nolan.

(2009), Non-persone: L'esclusione dei migranti in una società globale ('Non-persons:

Migrant Exclusion in a Global Society'), 2nd ed., Milano: Feltrinelli.

Dijk, T. A. Van (1988), News as Discourse, Hillsdale: Lawrence Erlbaum. 
Dijk, T. A. Van (2000), 'Ideology and discourse: A multidisciplinary introduction', http://www.discourses.org/UnpublishedArticles/Ideology\%20and\%20discourse.pdf. Accessed 22 January 2016.

Fairclough, N. (1989), Language and Power, New York: Longman.

(1995a), Critical Discourse Analysis: The Critical study of Language, London and New York: Longman.

(1995b), Media Discourse, London: Arnold.

Gabrielatos, C. and Baker, P. (2008), 'Fleeing, sneaking, flooding: A corpus analysis of discursive constructions of refugees and asylum seekers in the UK press, 1996-2005', Journal of English Linguistics, 36:1, pp. 5-38.

Hill, A. (2007), Restyling Factual TV: Audience \& News, Documentary \& Reality Genres, London and New York: Routledge.

Lakoff, G. and Johnson, M. (1980), Metaphors we Live By, Chicago: Chicago University Press.

Liberti, Stefano and Segre, Andrea (2012), Mare chiuso (Closed Sea), Italy: ZaLab.

Maneri, M. (1995), Stampa quotidiana e senso comune nella costruzione sociale dell'immigrato ('Daily news and common sense in the social construction of the immigrant'), Ph.D. thesis, Trento: University of Trento. 
Mauro, T. de (1963), Storia linguistica dell'Italia unita ('Linguistic history of United Italy)', Roma to Bari: Laterza.

Mengaldo, P. (1994), Il Novecento ('The nineteenth century'), Bologna: il Mulino.

Ministero dell'Interno (2007), Rapporto sulla criminalità in Italia: Analisi, Prevenzione, Contrasto ('Italy crime report: Analysis, prevention, contrast'), Ministero dell'Interno: Rome, http://www.interno.gov.it/mininterno/export/sites/default/it/assets/files/14/0900_rapporto _criminalita.pdf. Accessed 2 March 2016.

Montali, L., Riva, P., Frigerio, A. and Mele, S. (2013), 'The representation of migrants in the Italian press. A study on the Corriere della Sera (1992-2009)', Journal of Language and Politics, 12:2, pp. 226-50.

Musolff, A. (2010), Metaphor, Nation and the Holocaust: The Concept of the Body Politics, London and New York: Routledge.

Nichols, B. (2001), Introduction to Documentary, Bloomington: Indiana University Press.

O’Healy, Á. (2009), ““[Non] è una somala”: Deconstructing African femininity in Italian film', The Italianist, 29:2, pp. 175-98. 
Orrù, P. (2015), Razzismo quotidiano: la rappresentazione dello straniero nella stampa italiana (2000-2010) ('Daily racism: The representation of foreigners in the Italian press (2000/2010)'), Ph.D. thesis, Cagliari: University of Cagliari.

Quasthoff, U. (1989), 'Social prejudice as a resource of power: Towards the functional ambivalence of stereotypes', in R. Wodak (ed.), Language, Power and Ideology: Studies in Political Discourse, Amsterdam: Johh Benjamins, pp. 181-96.

Reisigl, M. and Wodak, R. (2001), Discourse and Discrimination: Rhetorics of Racism and Antisemitism, London and New York: Routledge.

Richardson, J. E. (2007), Analysing Newspapers: An Approach from Critical Discourse Analysis, New York: Palgrave MacMillan.

Richardson, J. E. and Colombo, M. (2013), 'Continuity and change in anti-immigrant discourse in Italy: An analysis of the visual propaganda of the Lega Nord', Journal of Language and Politics, 12:2, pp. 180-202.

Ricucci, Amedeo (2015), La lunga marcia ('The long route'), Italy: RAI Radiotelevisione Italiana.

Rossi, F. (2006), Il linguaggio cinematografico ('The filmic language'), Roma: Aracne.

Russo Bullaro, G. (ed.) (2010), From Terrone to Extracomunitario: New Manifestations of Racism in Contemporary Italian Cinema, London: Troubador Publishing. 
Taylor C. (2009), 'The representation of immigrants in the Italian press', CIRCaP Occasional Papers, 21, pp. 1-40, http://www.circap.org/uploads/1/8/1/6/18163511/occ_21_2009.pdf. Accessed 16 July 2016.

Ter Wal, J. (2001), 'Minacce territoriali, socio-economiche e di sicurezza. L'immagine degli immigrati nella stampa quotidiana' ('Territorial social, economic, and security threats. The representation of immigrants in the news'), Incontri, 16, pp. 67-78.

Vaccari, C. (2010), 'Missed opportunities: The debate on immigrants' voting rights in Italian newspapers and television', in M. Ardizzoni and C. Ferrari (eds), Beyond Monopoly: Globalization and Contemporary Italian Media, Lanham: Lexington Books, pp. 203-24.

Valk, I. van der (2003), 'Right-wing parliamentary discourse on immigration in France', Discourse and Society, 14:3, pp. 309-48.

Wodak, R. (2001), 'What CDA is about - a summary of its history, important concepts and its developments', in R. Wodak and M. Meyer (eds), Methods of Critical Discourse Analysis, London: Sage, pp. $1-13$.

\section{Contributor details}

Paolo Orrù (Ph.D.) is senior lecturer in Italian Linguistics at the University of Debrecen, Hungary. His main research interest is the linguistic representations of social issues including racism and homophobia in Italian media (newspapers, the Internet and cinema). His publications include 'Il discorso sulle migrazioni nell'Italia contemporanea: un'analisi 
linguistico-discorsiva sulla stampa (2000-2010)' (Franco Angeli, forthcoming), 'Racist discourse on social networks: a discourse analysis of Facebook posts in Italy' (Rhesis: International Journal of Linguistics, Philology and Literature, 2014), 'Lingua e alterità: lo stereotipo dell'omosessuale nel cinema italiano del Novecento' (Lingua Italiana d'Oggi, Bulzoni, 2012), and 'Il partito dell'amore e il partito dell'odio: analisi linguistica del conflitto politico nell'Italia della Seconda Repubblica' (Letterature straniere \&, Aracne, 2013). His current research focuses on populism and political language; second language acquisition and language testing; sociolinguistics and the urban space.

Contact:

Debreceni Egyetem Olasz Tanszék, Egyetem ter 1, 4032, Debrecen, Hungary. E-mail: paolo.orru1@gmail.com

\section{Notes}

${ }^{1}$ The vast majority of illegal immigrants in Italy belong to the category of the so-called overstayers (i.e. people who entered the country with a valid visa and remained in Italy after the document expired), with rates between $59 \%$ in 2000 and $64 \%$ in 2006 , peaking at $75 \%$ in 2003 (Ministero dell'Interno 2007).

2 'The Italian Cinema and Immigration Database', coordinated by Guido Bonsaver, in collaboration with Franca Pellegrini and Giancarla Vanoli, is a powerful reference tool that provides better insight into the dimension and evolution of the phenomenon (http://www.modlangs.ox.ac.uk/mml_apps/italian_movies/). While the Immigration Database comprises only fiction films produced and distributed between 1980 and 2010, the Archivio memorie migranti (www.archiviomemoriemigranti.net) could be a fruitful research instrument to investigate other formats, such as short films and documentaries. 
3 'For most people factual television is concerned with knowledge about the real world; as this viewer explains, 'factual means that the programme will contain facts and no fiction. Programmes that are true and about real issues'. This is an idealized view of factual television, and the tensions between ideals and practices make the production and reception of factuality challenging and dynamic' (Hill 2007: 3).

${ }^{4}$ Together with cinema and filmmaking (Rossi 2006).

${ }^{5}$ Unless otherwise indicated, all translations from the original (e.g. Italian) are mine.

6 The text is from the press kit of the film and can also be read on: https://www.youtube.com/watch?v=XX2At-y1bpc. Accessed 22 January 2016.

${ }^{7}$ Closed Sea (2012) by Liberti and Segre is an excellent example of what a documentary can accomplish, where the participatory nature of the film matches the direct involvement of the migrants and 'provides a stark contrast to the polished and dramatized coverage by television news and the out-of-touch analysis of government officials' (Ardizzoni 2013: 321). For a more in-depth analysis of Closed Sea, see (2013).

8 “"Aggregation" designates the quantification of groups of participants; it means the linguistic treatment of persons as numbers and statistics by means of definite or indefinite quantifiers' (Reisigl and Wodak 2001: 53).

${ }^{9}$ See Musolff (2010) for an extensive overview of metaphors and body politics in political discourse.

${ }^{10}$ According to Van der Valk the metaphor of 'water' 'symbolizes the loss of control over immigration. Too many immigrants enter the country. We lost control over the process' (2003: $331)$. 
For it is the force of ambivalence that gives the colonial stereotype its currency: ensures its repeatability in changing historical and discursive conjunctures; informs its strategies of individuation and marginalization; produces that effect of probabilistic truth and predictability which, for the stereotype, must always be in excess of what can be empirically proved and logically construed. (Bhabha 1994: 66) 